\title{
PEMANFAATAN COST PROFIT VOLUME ANALISYS
}

\author{
Oleh : Ec.Elfreda Aplonia Lau \\ Elfredalau9@gmail.com
}

Dosen Fakultas Ekonomi Universitas 17 Agustus 1945 Samarinda

\begin{abstract}
This descriptive research aims to describe cost profit, volume analysis and show its use in determining the minimum production quantities that must be produced and sold in various conditions where changes in selling prices, changes in variable costs, changes in fixed costs or changes in the composition of the sales mix. Do these changes have an impact on cost profit volume analysis or BEP?

This study also aims to apply the use of Cost profit volume analysis in sales or production planning, planning for normal selling prices, planning for production methods and determining the plant's closing point (shut down point)

The results showed that: 1 . BEP can change because of a. there is a change in the selling price while the costs are fixed, there will be a change in the Break Even Point, if there is an increase in the selling price it will decrease the BEP point. And vice versa if there is a determination of the selling price it will raise the BEP point. $b$ ) changes in variable costs with fixed selling price conditions, there will be a change in Braek Even Point points in proportion to these changes, i.e. if an increase in variable costs will increase the BEP point. And vice versa if there is a variable cost determination will reduce the point BEP.c) changes in fixed costs with the variable costs and fixed prices, there will be a change in the Braek Even Point point proportionally to these changes, if an increase in fixed costs will increase the point BEP And vice versa if there is a fixed cost determination will reduce the BEP point. 2. BEP can be used for sales or production planning in order to obtain the desired profit. 3. BEP can be used for planning the normal selling price, ie the selling price of a product that can help the company achieve the desired profit target.4 BEP can be used in the selection of production methods (labor intensive or capital intensive) .5 BEP can be used to close the company or not.
\end{abstract}

Keywords: Cost, Volume, Selling Price, Profit, BEP 


\section{PENDAHULUAN}

Awal analisis yang harus dilakukan oleh setiap perusahaan terutama yang berorientasi pada profit adalah analisis biaya,volume dan laba atau analisis pulang pokok atau analisis titik impas atau Analisis Break Even Point.Hal ini didasarkan pada pertimbangan bahwa perusahaan pada umumnya didirikan dengan tujuan mencapai keuntungan yang optimal. Namun fakta menunjukkan bahwa tidak selamanya demikian, bahkan kadang perusahaan merugi. Dengan demikian penting untuk melakukan analisis terhadap faktor-faktor pembentuk laba. Analisis inilah yang disebut sebagai analisis Break Even Point atau disingkat BEP. Dasar yang digunakan dalam analisis ini adalah perilaku biaya dalam kaitannya dengan hasil penjualan.

Berdasarkan paparan tersebut dianggap penting untuk menjelaskan dan menunjukkan pemanfaatan analisis Break Even Point untuk menentukan jumlah produksi minimal yang harus diproduksi dan dijual pada berbagai kondisi dimana terjadi perubahan harga jual, terjadi perubahan biaaya variabel, terjadi perubahan biaya tetap. Demikian pula pemanfaatan analisis biaya, volume dan laba ini dalam menentukan : merencanakan penjualan dan produksi, merencanakan harga jual normal, merencanakan metode produksi dan menemukan titik tutup pabrik.

\section{KERANGKA DASAR TEORI}

Teori yang melandasi penelitian ini adalah Cost, Profit,Volume (Cost, Profit, Volume Analisys) yaitu analisis didasarkan pada perilaku biaya dalam kaitannya dengan hasil penjualan dan lasimnya disebut sebagai Break Even Point atau BEP. Dalam kaitannya dengan volume penjualan maka biaya dibagi menjadi biaya variabel dan biaya tetap. Biaya variabel. Dalam kaitannya dengan volume penjualan, maka biaya variabel adalah biaya yang secara total berubah-ubah sesuai dengan perubahan volume penjualan.Atau biaya total yang berubah-ubah dan perubahannya proporsional dengan perubahan volume penjualan, namun perunitnya tetap. Sedangkan Biaya Tetap adalah biaya yang tidak terpengaruh oleh perubahan volume kegiatan, tetapi perunitnya berubah-ubah.

BEP hanya bisa terjadi bila terdapat dua jenis biaya yaitu biaya variabel dan biaya tetap. Penghasilan dikurangi dengan biaya variabel merupakan bagian dari penghasilan yang tersedia untuk menutup biaya tetap dan disebut sebagai $C M$ (contribution margin). Jika CM>biaya tetap berarti perusahaan dalam kondisi Laba/untung. Sebaliknya jika $\mathrm{CM}<$ biaya tetap berarti perusahaan dalam kondisi rugi. Jika $\mathrm{CM}=$ biaya tetap maka terjadi BEP. 
BEP dapat ditentukan pendekatan grafik dan pendekatan matematik. Pendekatan grafik yaitu suatu pendekatan penentuan titik brek even dengan menggambarkan unsur-unsur biaya dan penghasilan ke dalam suatu gambar grafik, dimana dapat terbaca biaya variabel, biaya tetap, biaya total dan garis total penghasilan. Pendekatan matematik dapat dilakukan dengan dua cara yaitu:BEP atas dasar unit dan BEP atas dasar rupiah.

Perubahan pada biaya variabel, harga jual, biaya tetap dan komposisi sales mix dapat menyebabkan perubahan titik Break Even Point.

\section{METODE PENELITIAN}

Variabel dasar dalam penelitian ini adalah biaya,volume, laba, harga jual. Biaya variabel. Dalam kaitannya dengan volume penjualan, adalah biaya variabel dan biaya tetap. Biaya variabel adalah biaya yang secara total berubah-ubah sesuai dengan perubahan volume penjualan atau biaya total yang berubah-ubah dan perubahannya proporsional dengan perubahan volume penjualan, namun perunitnya tetap.Biaya Tetap adalah biaya yang tidak terpengaruh oleh perubahan volume kegiatan, tetapi perunitnya berubah-ubah. Sedangkan yang dimaksud dengan volume adalah Banyaknya jumlah barang yang dijual. Selanjutnya yang dimaksudkan dengan laba adalah selisih dari harga penjualan dengan biaya yang dipakai saat melakukan produksi. Harga jual adalah sejumlah uang yang ditetapkan akan diterima dari setiap satuan produk yang dihasilkan dan akan dijual

Alat analisis yang digunakan dalam penelitian ini adalah analisis Break Even Point yang dinyatakan dalam unit diperoleh dengan rumus maupun dalam rupih.BEP Unit.Q=BT:(P-V). Sementara Rumus BEP Rp = $\mathrm{BT} /(1-\mathrm{V} / \mathrm{P})$ dimana : $\mathrm{P}=$ Harga jual per unit, $\mathrm{V}=$ Biaya variabel perunit, $\mathrm{BT}=\mathrm{Biaya}$ tetap total selama satu tahun dan $\mathrm{Q}=$ Kuantitas penjualan

\section{ANALISIS DAN PEMBAHASAN}

Analisis BEP dapat dilakukan dengan dua cara yaitu pendekatan grafik dan pendekatan matematik. Pendekatan grafik yaitu suatu pendekatan penentuan titik brek even dengan menggambarkan unsur-unsur biaya dan penghasilan ke dalam suatu gambar grafik, dimana dapat terbaca biaya variabel, biaya tetap, biaya total dan garis total penghasilan yang dapat diikuti melalui ilustrasi berikut ini : Perusahaan "CS" menjual produknya dengan harga per unit Rp 50.000,-Biaya variabel yang dikeluarkan sebesar Rp 30.000,-dan biaya tetapnya selama 1 tahun Rp 600.000.000. maka BEP dapat ditentukan berikut ini : 
Tabel 1

PERSIAPAN BEP GRAFIK

\begin{tabular}{|r|r|r|r|r|}
\hline $\begin{array}{c}\text { Q } \\
\text { (unit) }\end{array}$ & $\begin{array}{c}\text { BiayaVariabel } \\
(\mathbf{R p})\end{array}$ & $\begin{array}{c}\text { BiayaTetap } \\
(\mathbf{R p})\end{array}$ & $\begin{array}{c}\text { Total Biaya } \\
(\mathbf{R p})\end{array}$ & \multicolumn{1}{|c|}{$\begin{array}{c}\text { Total } \\
\text { Penghasilan } \\
(\mathbf{R P})\end{array}$} \\
\hline 0 & 0 & 600.000 .000 & 600.000 .000 & 0 \\
\hline 10.000 & 300.000 .000 & 600.000 .000 & 900.000 .000 & 500.000 .000 \\
\hline 20.000 & 600.000 .000 & 600.000 .000 & 1.200 .000 .000 & 1.000 .000 .000 \\
\hline 30.000 & 900.000 .000 & 600.000 .000 & 1.500 .000 .000 & 1.500 .000 .000 \\
\hline
\end{tabular}

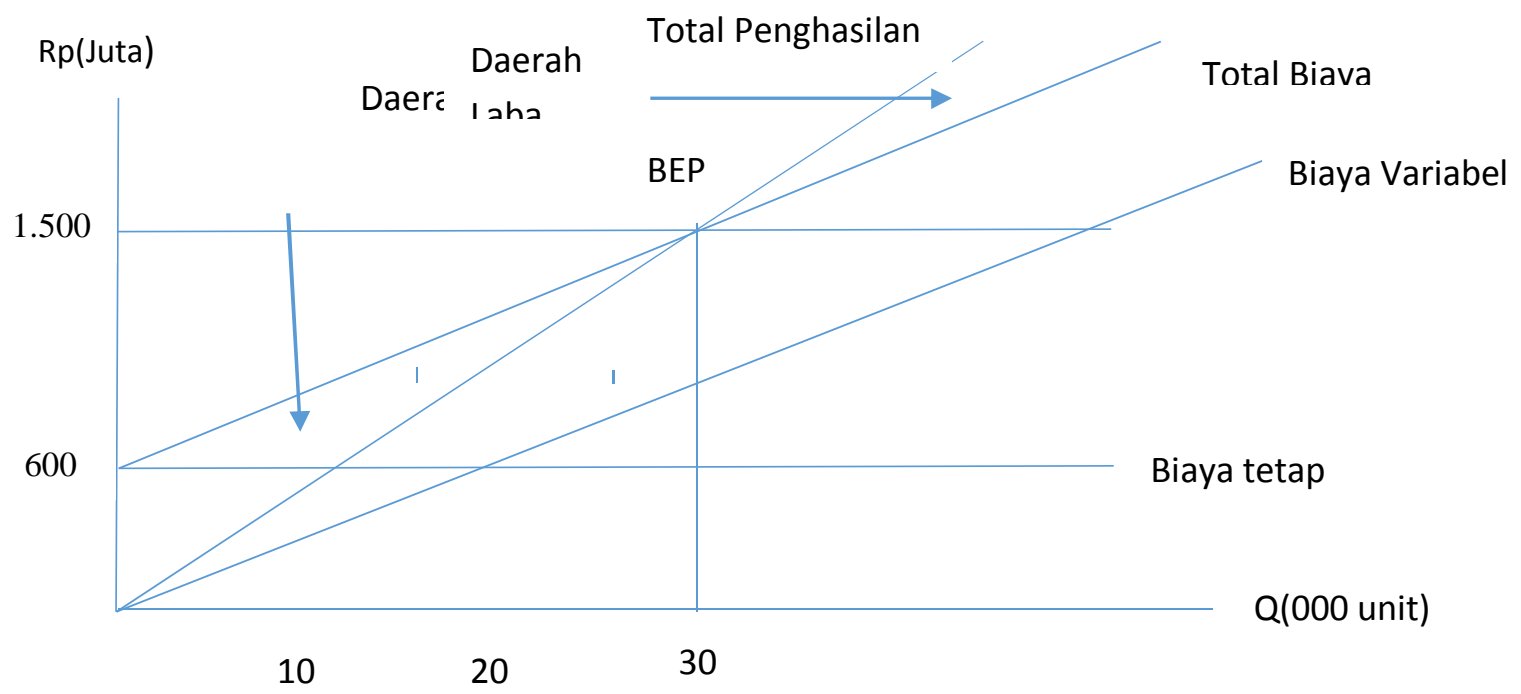

Dari gambar tersebut Nampak bahwa BEP tercapai pada saat perpotongan antara garis total biaya dengan garis penghasilan yakni sebesar Rp 1.500.000.000 dan 30.000 unit. Sebelah kanan BEP terdapat daerah laba dan sebelah kirinya menunjukkan daerah rugi.

Analisis BEP dapat dilakukan dengan pendekatan matematik. Pendekatan ini dapat dilakukan dengan dua cara yaitu:BEP atas dasar unit dan BEP atas dasar rupiah. Pada keadaan BEP berarti perusahaan tidak memperoleh laba dan tidak mengalami kerugian dimana Total Penghasilan=Total Biaya atau Laba sama dengan nol sehingga persamaan BEP : Penghasilan = Biaya

bila: $\mathrm{P}=$ Harga jual per unit, $\mathrm{V}=$ Biaya variabel perunit, $\mathrm{BT}=\mathrm{Biaya}$ tetap total selama satu tahun dan $\mathrm{Q}=$ Kuantitas penjualan Maka :

P.Q=VQ+BT

$\mathrm{PQ}-\mathrm{VQ}=\mathrm{BT}$

$(\mathrm{P}-\mathrm{V}) \mathrm{Q}=\mathrm{BT}$

$\mathrm{Q}=\mathrm{BT}:(\mathrm{P}-\mathrm{V})$ Rumus BEP Unit.

$\mathrm{BEP} \mathrm{Rp}=\mathrm{BT} /(1-\mathrm{V} / \mathrm{P})$ 
Sehingga bila merujuk pada ilustrasi tersebut maka

BEP unit $=$ Rp 600.000.000 : (Rp50.000/unit-Rp30.000/unit $)$

$$
=\operatorname{Rp} 600.000 .000: \operatorname{Rp} 20.000 / \text { unit }=30.000 \text { unit }
$$

BEP Rp = Rp 600.000.000:(1-Rp30.000/Rp50.000)

$$
\begin{gathered}
=\operatorname{Rp} 600.000 .000:(1-0,6)=\operatorname{Rp} 600.000 .000: 0,4 \\
=\operatorname{Rp~1.500.000.000~}
\end{gathered}
$$

Rumus BEP menggunakan CMR(Contribution Margin Ratio), dalam contoh ini diperoleh dari $:=1-\frac{R p 30.000}{R p 50.000 !}=0,4$ artinya bahwa setiap perubahan penjualan akan diikuti perubahan biaya variabel sebesar $60 \%$.

Titik BEP ini dapat berubah karena beberapa faktor yaitu:

\section{Perubahan Harga Jual}

Perubahan harga jual akan mempengaruhi besarnya titik BEP. Jika harga jual per unit mengalami kenaikan sedangkan biaya tidak mengalami perubahan, maka akan menurunkan titik BEP. Sebaliknya, jika harga jual per unit mengalami penurunan sedangkan biaya tidak mengalami perubahan, maka akan menaikkan titik BEP.

\section{Contoh:}

Perusahaan"CS" memiliki data harga jual per unit Rp 20.000,- Biaya variabel per unit Rp12.000,- Biaya tetap per tahun Rp 300.000.000, maka $\mathrm{BEP}_{\mathrm{Rp}}=\frac{R p 300.000 .000}{1-R p \frac{12.000}{R p 20.000}}=\operatorname{Rp} 750.000 .000$

Pada periode tersebut jika terjadi kenaikan harga jual per unit dari $\mathrm{Rp}$ 20.000 menjadi Rp 25.000 per unit, maka $\mathrm{BEP}_{\mathbf{R p}}=\frac{R p 300.000 .000}{1-R p \frac{12.000}{R p 25.000}}=$ Rp 576.923.077 dengan demikian titik BEP turun dari Rp750.000.000 menjadi Rp576.923.077

Penurunan ini terjadi pula pada BEP unit. Hal ini dapat dikuti pada perhitungan berikut ini:

$\mathrm{BEP}_{\text {Unit pada harga jual Rp 20.000/unit }}=\frac{R p 300.000 .000}{R p 20.000-R p 12.000}=37.500$ Unit

$\mathrm{BEP}_{\text {Unit pada harga jual Rp 25.000 }}=\frac{R p 300.000 .000}{R p 25.000-R p 12.000}=23.077$ Unit

\section{Perubahan Biaya Variabel Perunit}

Perubahan pada biaya variabel juga akan merubah titik BEP dan dapat diikuti melalui ilustrasi berikut ini :

Perusahaan"CS" memiliki data harga jual per unit Rp 20.000,- Biaya variabel per unit $\mathrm{Rp} 12.000$,- Biaya tetap per tahun $\mathrm{Rp} 300.000 .000$, maka $\mathrm{BEP}_{\mathrm{Rp}}=\frac{R p 300.000 .000}{1-R p \frac{12.000}{R p 20.000}}=R p 750.000 .000$ 
Pada periode tersebut jika terjadi kenaikan biaya variabel per unit dari Rp 12.000 menjadi $\mathrm{Rp} 15.000$ per unit, maka $\mathrm{BEP}_{\mathrm{Rp}}=\frac{R p 300.000 .000}{1-R p \frac{15.000}{R p 20.000}}=$ $R p$ 1.200.000.000 dengan demikian titik BEP naik dari Rp750.000.000 menjadi Rp 1.200.000.000

Kenaikan ini terjadi pula pada BEP unit. Hal ini dapat dikuti pada perhitungan berikut ini:

$\mathrm{BEP}_{\text {Unit pada biaya variabel } \mathrm{Rp} 12.000 / \mathrm{unit}}=\frac{R p 300.000 .000}{R p 20.000-R p 12.000}=37.500$ Unit
$\mathrm{BEP}_{\text {Unit pada biaya variabel } \mathrm{Rp} 15.000}=\frac{R p 300.000 .000}{R p 20.000-R p 15.000}=60.000$ Unit

Perubahan pada biaya variabel juga akan merubah titik BEP, yakni apabila biaya variabel naik akan menaikkan titik BEP dan bila biaya variabel turun akan menurunkan BEP

\section{Perubahan Biaya Tetap}

Perubahan biaya tetap akan juga merubah posisi BEP menjadi lebih besar bila biaya tetap naik. Sebaliknya bila biaya tetap mengalami penurunan, maka BEP akan mengalami penurunan.

Perusahaan"CS" memiliki data harga jual per unit Rp 20.000,- Biaya variabel per unit Rp12.000,- Biaya tetap per tahun Rp 300.000.000, maka $\mathrm{BEP}_{\mathrm{Rp}}=\frac{R p 300.000 .000}{1-R p \frac{12.000}{R p 20.000}}=R p 750.000 .000$

Pada periode tersebut jika terjadi kenaikan biaya tetap dari $\mathrm{Rp}$ 300.000.000 menjadi sebesar Rp 400.000.000, maka $\mathrm{BEP}_{\mathrm{Rp}}=$ $\frac{R p 400.000 .000}{1-R p \frac{12.000}{R p 20.000}}=R p 1.000 .000 .000$ dengan demikian titik BEP naik dari Rp750.000.000 menjadi Rp 1.000.000.000

Kenaikan ini terjadi pula pada BEP unit. Hal ini dapat dikuti pada perhitungan berikut ini:

$\mathrm{BEP}_{\text {Unit pada biaya tetap } 1 \mathrm{Rp} 300.000 .000}=\frac{R p 300.000 .000}{R p 20.000-R p 12.000}=37.500$ Unit

$\mathrm{BEP}_{\text {Unit pada biaya tetap } 1 \mathrm{Rp} 400.000 .000}=\frac{R p 400.000 .000}{R p 20.000-R p 12.000}=50.000$ Unit

\section{Perubahan Komposisi Sales Mix}

Pada asumsi dinyatakan pula bahwa perusahaan hanya menghasilkan satu macam produk dan bila menghasilkan lebih dari dua macam produk, maka tidak boleh ada perubahan komposisi dalam sales mix nya.

Sales mix menunjukkan pertimbangan penjualan antara beberapa macam produk yang dihasilkan. Jika terjadi perubahan sales mixnya maka akan menyebabkan perubahan pada BEP secara total.

Perusahaan"CS" memproduksi dua jenis produk dengan data-data sebagai berikut : 
Tabel 2

DATA KOMPOSISI SALES MIX PERUSAHAAN"CS"

\begin{tabular}{|l|r|r|r|}
\hline \multicolumn{1}{|c|}{ Keterangan } & \multicolumn{1}{c|}{$\begin{array}{c}\text { Produk A } \\
\text { (20.000 Unit) }\end{array}$} & $\begin{array}{c}\text { Produk B } \\
(\mathbf{8 . 0 0 0} \text { Unit })\end{array}$ & \multicolumn{1}{c|}{ Total } \\
\hline $\begin{array}{l}\text { Penjualan (Rp) } \\
\text { Biaya }\end{array}$ & 500.000 .000 & 500.000 .000 & 1.000 .000 .000 \\
Variabel(Rp) & 300.000 .000 & 200.000 .000 & 500.000 .000 \\
\hline $\begin{array}{l}\text { Kontribusi } \\
\text { Margin(Rp) }\end{array}$ & 200.000 .000 & 300.000 .000 & 500.000 .000 \\
\hline $\begin{array}{l}\text { Biaya } \\
\text { Tetap(Rp) }\end{array}$ & 100.000 .000 & 200.000 .000 & 300.000 .000 \\
\hline Laba & 100.000 .000 & 100.000 .000 & 200.000 .000 \\
\hline
\end{tabular}

Harga produk $A=R p 25.000$ dan Harga produk $Y=R p 62.500$

Berdasarkan data tersebut :

Sales Mix $=500.000 .000: 500.000 .000$ atau $1: 1$

Product Mix $=20.000$ unit $: 8.000$ unit atau 2,5:1

$\mathrm{BEP}_{\text {Total }}$

$=\frac{\text { Biaya Tetap Total }}{1-R p \frac{\text { Biaya Variabel Total }}{\text { Penjualan Total }}}=\frac{R p 300.000 .000}{1-R p \frac{500.000 .000}{R p 1.000 .000 .000}}=R p 600.000 .000$

Alokasi BEP pada produk A dan Produk Berdasarkan komposisinya yaitu perbandingan 1:1 sebagai berikut :

Penjualan produk $A=1 / 2 \quad x \operatorname{Rp} 600.000 .000=R p 300.000 .000$ dan penjuialan produk $B=1 / 2 \times \operatorname{Rp} 600.000 .000=R p 300.000 .000$.

BEP dalam unitnya :

Produk A = Rp 300.000.000: $\quad$ Rp 25.000/Unit $=12.000$ unit

Produk B $=$ Rp 300.000.000 : $\quad$ Rp 62.500/unit $=4.800$ unit

Atau dalam perbandingan 12.000 unit : 4.800 unit $=2,5: 1$ sama dengan komposisi produk mix

BEP salles mix sebesar Rp 600.000.000 tersebut tidak berarti bahwa produk A mengalami kondisi BEP demikian pula dengan produk B. Melainkan BEP yang tercapai tersebut merupakan BEP gabungan, sehingga dapat saja satu produknya untung sedangkan produk lainnya tidak. 
Bila dilihat dalam komposisi labanya sebagai berikut :

Tabel 3

KOMPOSISI LABA

\begin{tabular}{|l|r|r|r|}
\hline \multicolumn{1}{|c|}{ Keterangan } & $\begin{array}{l}\text { Produk A } \\
\text { (12.000 Unit) }\end{array}$ & $\begin{array}{l}\text { Produk B } \\
\text { (4.800 Unit) }\end{array}$ & Total \\
\hline $\begin{array}{l}\text { Penjualan (Rp) } \\
\text { Biaya }\end{array}$ & 300.000 .000 & 300.000 .000 & 600.000 .000 \\
Variabel(Rp) & 180.000 .000 & & 300.000 .000 \\
\hline $\begin{array}{l}\text { Kontribusi } \\
\text { Margin(Rp) }\end{array}$ & 120.000 .000 & 180.000 .000 & \\
\hline $\begin{array}{l}\text { Biaya } \\
\text { Tetap(Rp) }\end{array}$ & 100.000 .000 & 200.000 .000 & 300.000 .000 \\
\hline Laba & 20.000 .000 & $(20.000 .000)$ & 0000.000 \\
\hline
\end{tabular}

Bagaimana pengaruhnya apabila terjadi perubahan terhadap komposisi penjualan terhadap BEP salesmixnya?

a. Bila produk A naik 50\%, produk A tetap, maka BEPnya adalah:

\section{Tabel 4}

KOMPOSISI LABA BILA PRODUK A NAIK 50\%

\begin{tabular}{|c|c|c|c|}
\hline Keterangan & $\begin{array}{l}\text { Produk A } \\
\text { (30.000 Unit) }\end{array}$ & $\begin{array}{l}\text { Produk B } \\
\text { (8.000 Unit) }\end{array}$ & Total \\
\hline Penjualan (Rp) & 750.000 .000 & 500.000 .000 & 1.250 .000 .000 \\
\hline Biaya & 450.000 .000 & & 650.000 .000 \\
\hline Variabel(Rp) & & 200.000 .000 & \\
\hline $\begin{array}{l}\text { Kontribusi } \\
\text { Margin(Rp) }\end{array}$ & 300.000 .000 & 300.000 .000 & 600.000 .000 \\
\hline $\begin{array}{l}\text { Biaya } \\
\text { Tetap(Rp) }\end{array}$ & 100.000 .000 & 200.000 .000 & 300.000 .000 \\
\hline Laba & 200.000 .000 & 100.000 .000 & 300.000 .000 \\
\hline
\end{tabular}

$\mathrm{BEP}_{\text {Total }}$

$=\frac{\text { Biaya Tetap Total }}{1-R p \frac{\text { Biaya Variabel Total }}{\text { Penjualan Total }}}=\frac{R p 300.000 .000}{1-R p \frac{650.000 .000}{R p 1.250 .000 .000}}=R p 625.000 .000$

b. Bila produk B naik 50\% dan produk A tetap, maka BEPnya adalah : 


\section{Tabel 5}

KOMPOSISI LABA BILA PRODUK B NAIK 50\%

\begin{tabular}{|l|r|r|r|}
\hline \multicolumn{1}{|c|}{ Keterangan } & $\begin{array}{l}\text { Produk A } \\
(20.000 \text { Unit })\end{array}$ & $\begin{array}{l}\text { Produk B } \\
(12.000 \text { Unit })\end{array}$ & Total \\
\hline $\begin{array}{l}\text { Penjualan (Rp) } \\
\text { Biaya } \\
\text { Variabel(Rp) }\end{array}$ & 500.000 .000 & 750.000 .000 & 1.250 .000 .000 \\
650.000 .000 & & 300.000 .000 & \\
\hline $\begin{array}{l}\text { Kontribusi } \\
\text { Margin(Rp) }\end{array}$ & 200.000 .000 & 450.000 .000 & 600.000 .000 \\
\hline $\begin{array}{l}\text { Biaya } \\
\text { Tetap(Rp) }\end{array}$ & 100.000 .000 & 200.000 .000 & 300.000 .000 \\
\hline Laba & 100.000 .000 & 250.000 .000 & 350.000 .000 \\
\hline
\end{tabular}

$\mathrm{BEP}_{\text {Total }}$

$=\frac{\text { Biaya Tetap Total }}{1-R p \frac{\text { Biaya Variabel Total }}{\text { Penjualan Total }}}=\frac{R p 300.000 .000}{1-R p \frac{600.000 .000}{R p 1.250 .000 .000}}=R p 576.923 .000$

Break Even Point atau BEP dapat dimanfaatkan pula untuk :

\section{a. Perencanaan Penjualan atau produksi}

Setiap perusahaan hendaknya memiliki perencanaan produksi dan penjualan. Hal ini dapat didasarkan pada konsep BEP. Penjualan yang direncanakan tentunya disertai dengan target laba tertentu, sehingga rencana penjualan minimum adalah:

$\mathrm{PM}_{\text {Unit }}=(\mathrm{BT}+\mathrm{Laba}):(\mathrm{P}-\mathrm{V})$ sedangkan penjualan minimal dalam rupiah adalah:

$\mathrm{PM}_{\text {Rupiah }}=(\mathrm{BT}+\mathrm{Laba}):(1-\mathrm{V} / \mathrm{P})$

Contoh :

Perusahaan "CS" mempunyai kapasitas normal 50.000 unit per tahun, namun pada tahun 2020 perusahaan berencana untuk menghasilkan 30.000 unit produk dengan biaya per unit sebagai berikut :

Biaya Bahan baku Rp 7.000

BTKL

Rp 5.000

BOP Variabel

Rp 4.000

BOP Tetap

$\mathrm{Rp} 5.500$

Biaya komersial variabel $\quad \mathrm{Rp} 2.000$

Biaya komersial tetap

Rp 2.500

Produk yang dihasilkan dijual dengan harga per unit Rp30.000,-

Hitunglah :

1). BEP

2). Besarnya penjualan minimal bila ditetapkan target laba:

a). $\operatorname{Rp} 180.000 .000,-$

b). $15 \%$ dari penjualan

c). $25 \%$ dari biaya variabel

3). Margin of safety sesui ketentuan butir $2 b$ 
Penyelesaian :

1). $\mathrm{BEP}_{\text {unit }}=\mathrm{BT}:(\mathrm{P}-\mathrm{V})=\mathrm{Rp} 240.000 .000:(\mathrm{Rp} 30.000 /$ unit $-\mathrm{Rp}$ 18.000/unit)

$$
=\underset{\text { unit }}{\operatorname{Rp} 240.000 .000:(\operatorname{Rp~12.000/unit~})=20.000}
$$

Biaya variabel meliputi :

Biaya Bahan Baku

Biaya Tenaga Kerja Langsung

Rp 7.000,-

BOP Variabel

Rp 5.000,-

Biaya komersial variabel

Rp 4.000,-

$\operatorname{Rp} \quad 2.000,-$

Rp 18.000,-

Biaya Tetap Total = BOP Tetap + Biaya komersial tetap

$$
\begin{aligned}
& =(\operatorname{Rp} \operatorname{Rp} 5.500,-+\operatorname{Rp} 2.500)(30.000) \\
& =\operatorname{Rp} 240.000 .000
\end{aligned}
$$

Harga jual per unit Rp 30.000,-

$\mathrm{BEP}_{\text {Rupiah }}=\mathrm{BT}:(1-\mathrm{V} / \mathrm{P})=\mathrm{Rp} 240.000 .000:(1-\mathrm{Rp} 18.000 / \mathrm{Rp} 30.000)$ $=\operatorname{Rp} 600.000 .000$

2). Besarnya penjualan minimal bila ditetapkan target laba:

a). Rp 180.000.000,-

$$
\mathrm{BEP}_{\mathrm{Rp}}=\frac{\text { Biaya Tetap }+ \text { Target Laba }}{1-\frac{\text { Biaya } \frac{\text { variabel }}{\text { unit }}}{\text { Harga Jual per unit }}}=\frac{R p 240.000 .000+R p 180.000 .000}{1-\frac{R p 18.000}{R p 30.000}}
$$

\section{$=$ Rp 1.050.000.000.000}

b). Penjualan minimal bila dikehendaki laba $\mathbf{1 5 \%}$ dari penjualan

Bila penjualan minimal $=\mathrm{X} \quad \longrightarrow \quad$ Laba diinginka $=0,15 \mathrm{X}$

Maka X $=\frac{\text { Biaya } \text { Tetap }+ \text { Target Laba }}{1-\frac{\text { Biaya } \frac{\text { variabel }}{\text { unit }}}{\text { Harga Jual per unit }}}=\frac{R p 240.000 .000+0,15 X}{1-\frac{R p 18.000}{R p 30.000}}=R p 960.000 .000$

c). Penjualan minimal bila dikehendaki laba $25 \%$ dari biaya variabel

Bila penjualan minimal Q unit Laba $=0,25(18.000 Q)$

$\mathbf{Q}=\frac{\text { Biaya Tetap }+ \text { Target Laba }}{\text { Harga Jual per unit }- \text { Biaya variabel per unit }}=\frac{R p 240.000 .000+0,25(18.000 Q)}{R p 30.000 / \text { unit, }- \text { Rp } 18.000,-/ \text { unit }}=$ 
3). Margin of safety dengan anggaran penjualan $\mathrm{Rp} 960.000 .000$ adalah:

$$
\frac{\text { Biaya Tetap }+ \text { Target Laba }}{\text { Harga Jual per unit }- \text { Biaya variabel per unit }}=\frac{R p 960.000 .000+R p 600.000 .000}{R p 960.000 .000} \mathrm{X}
$$
$100 \%$

\section{b. Perencanaan Harga Jual Normal}

$$
=37,5 \%
$$

Manajemen perusahaan perlu menentukan harga jual. Harga jual merupakan sejumlah uang yang dibayarkan oleh pembeli untuk mendapatkan barang dan atau jasa yang dikendaki. Setiap perusahaan tentunya menghendaki harga jual harus dapat menutupi semua biaya dan target keuntungan.

Dalam menentukan harga jual perusahaan merujuk kepada proyeksi penjulan yang telah direncanakan dan target laba yang hendak diperoleh. Perusahaan "CS" memproyeksi penjualan tahun 2021 sebesar 100.000 unit sedangkan biaya variabel per unit Rp 50.000,-Biaya tetap sebesar Rp 750.000.000. Bila tahun 2021 ditargetkan laba sebesar Rp 500.000.000, maka berapakah perusahaan harus menjual produknya perunit?

Penyelesaian :

Diketahui :

Biaya variabel per unit Rp 50.000,- Biaya Tetap Rp 600.000.000,Laba $=$ Rp 500.000.000,- sedangkan $Q=100.000$ unit

Ditanya: Berapakah harga jual per unitnya?

Jawab :

$$
\mathrm{Q}=\frac{\text { Biaya Tetap }+ \text { Target Laba }}{\text { Harga Jual per unit-Biaya variabel per unit }}
$$

100.000 unit $=\frac{R p 7500.000 .000+R p 500.000 .000}{P-R p 50.000}$

$\mathrm{P}=\frac{R p 2.250 .000 .000}{50.000}=R p 50.013,-$

Dengan demikian perusahaan harus menetapkan harga jual per unitnya sebesar Rpp 50.013 supaya dapat memperoleh keuntungan yang diharapkan.

\section{c. Perencanaan Metode Produksi}

Analisis BEP digunakan juga untuk menentukan alternative penggunaan metode pengerjaan atau metode produksi padat karya(labour intensive atau padat modal(capital intensif). 
Ilustrasi penggunaan BEP dalam perencanaan metode produksi sebagai berikut:

$\begin{array}{llrlr} & \text { Mesin A } & \text { Mesin B } \\ \text { Harga jual per unit } & \mathrm{Rp} & 40.000,- & \mathrm{Rp} & 40.000,- \\ \text { Biaya variabel per unit } & \mathrm{Rp} & 24.000,- & \mathrm{Rp} & 20.000,- \\ \text { Biaya tetap se tahun } & \mathrm{Rp} \mathrm{800.000.000,-} & \mathrm{Rp} 1.600 .000 .000,- \\ \text { Metode produksi } & \text { Padat karya } & \text { Padat modal }\end{array}$

Mana yang sebaiknya dipilih oleh perusahaan?

$\mathrm{BEP}_{\text {Mesin } \mathrm{A}}=\frac{\text { Biaya Tetap }}{\text { Harga Jual per unit }- \text { Biaya variabel per unit }}=\mathrm{Rp}$ 800.000.000:

Rp $16.000=50.000$ unit

$\mathrm{BEP}_{\text {Mesin } \mathrm{B}}=\frac{\text { Biaya Tetap }}{\text { Harga Jual per unit }- \text { Biaya variabel per unit }}=\mathrm{Rp} 1.600 .000 .000:$

Rp $20.000=80.000$ unit

Dengan demikian apabila menggunakan dasar BEP, maka mesin A (padat karya) lebih baik sebab BEP nya rendah.

\section{d. Titik Tutup Pabrik}

Perusahaan dapat mendeteksi perusahaan masih dapat beroperasi dengan baik atau menghadapi masalah yang dapat menyebabkan perusahaan ditutup. Hal ini dapat dilihat dari penjualan total dan biaya total. Bila penjualan total lebih kecil dari biaya total atau biaya total melebihi penjualan total maka kemungkinan manajemen harus memutuskan untuk menutup perusahaannya.

Manajemen melakukan analisis titik tutup pabrik (shut down point) atau SDP

Apabila perusahaan beroperasi dibawah BEP berarti secara akuntansi mengalami kerugian.Namun secara cash flow(arus kas), perusahaan masih mendapatkan sisa kas selama penerimaan penghasilan masih dapat menutup biaya variabel dan biaya teteap tunai.

Biaya tetap tunai adalah biaya tetap yang dikeluarkan secara tunai seperti pembayaran gaji, biaya promosi, sewa gudang,dan biaya tetap tunai lainnya. Artinya perusahaan pada kondisi tersebut masih dapat membayar biaya gaji karywannya, meskipun tidak dapat menutup biaya tetap tidak tunai(penyusutan). Tetapi jika perusahaan sudah tidak dapat menutup biaya variabel dan biaya tetap tunai, maka perusahaan sudah harus ditutup.

Formula yang digunakan untuk menghitung SDP :

$\mathrm{SDP}=\frac{\text { Biaya Tetap Tunai }}{\text { Rasio Kontribusi Margin }}$

SDP merupakan pedoman bagi manajemen untuk memutuskan apakah perusahaan diteruskan atau dihentikan. Apabila penerimaan penjualan melebihi shut down point, maka sebaiknya perusahaan tetap beroperasi, 
tetapi jika penjualan sudah lebih kecil dari shut down point, sebaiknya perusahaan ditutup sebab perusahaan sudah tidak mampu membayar gaji maupun sewa.

Ilustasi penggunaan BEP sebagai titik tutup pabrik sebagai berikut :

Perusahaan"CS" menjual produknya dengan harga Rp 40.000,-per unit.Biaya variabel per unit Rp 24.000,- dengan Biaya Tetap sebesar Rp $600.000 .000(60 \%$ biaya tetap tunai), maka

$$
\begin{aligned}
\mathrm{BEP} & =\frac{\text { Biaya Tetap Tunai }}{\text { Rasio Kontribusi Margin }}=\frac{R p 600.000 .000}{1-R p 24.000 / \text { Rp } 40.000}=\frac{R p 600.000 .000}{1-0,6} \\
\mathrm{BEP} & =\frac{R p 600.000 .000}{0,4}=\operatorname{Rp} 1.500 .000 .000,-
\end{aligned}
$$

Pada konsep BEP tersebut secara akuntansi perusahaan tidak laba dan tidak rugi, tetapi secara cashflow mendapatkan laba tunai sebesar biaya tetap tidak tunai, yakni:

Penjualan

Biaya variabel

Biaya tetap tunai $(60 \% \times \mathrm{Rp} 600.000 .000=$

\section{Laba Tunai}

\section{$\underline{R p \quad 240.000 .000,--}$}

$\mathrm{SDP}==\frac{60 \% x \text { Biaya Tetap Tunai }}{\text { Rasio Kontribusi Margin }}==\frac{60 \%(\text { Rp 600.000.000 })}{0,4}=$ $\operatorname{Rp} 900.000 .000,-$

Pada saat shut down point, secara akuntansi perusahaan mengalami kerugian tetapi secara cashflow perusahaan tidak menerima laba tunai, seperti perhitungan di bawah ini :

Penjualan

Biaya variabel

Biaya tetap tunai $(60 \% \times \operatorname{Rp} 600.000 .000=$
$\mathrm{Rp}$

$\mathrm{Rp}$

Rp $\mathrm{Rp}$ 900.000.000,540.000.000,$\frac{360.000 .000,-+}{900.000 .000,--}$

\section{Laba Tunai}




\section{KESIMPULAN}

Berdasarkan analisis dan pembahasan disimpulkan bahwa :

1. Cost profit volume Analisys atau analisis Break Even Point disingkat BEP dapat berubah. Perubahan itu dapat terjadi karena :

a. Perubahan harga jual dengan syarat biaya-biaya tetap, maka akan terjadi perubahan titik Braek Even Point yaitu apabila terjadi kenaikan harga jual maka akan menurunkan titik BEP. Demikian pula sebaliknya bila terjadi penutunan harga jual per satuannya maka akan menaikan titik BEP.

b. Perubahan biaya variabel dengan sayarat harga jual tetap, maka akan terjadi perubahan titik Braek Even Point secara sebanding dengan perubahan tersebut yakni jika terjadi kenaikan biaya variabel maka akan menaikan titik BEP. Demikian pula sebaliknya bila terjadi penutunan biaya variabel maka akan menurunkan titik BEP.

c. Perubahan biaya tetap dengan syarat biaya variabel dan harga jual tetap maka akan terjadi perubahan titik Braek Even Point secara sebanding dengan perubahan tersebut yaitu apabila terjadi kenaikan biaya tetap maka akan menaikan titik BEP. Demikian pula sebaliknya bila terjadi penutunan biaya tetap maka akan menurunkan titik BEP

d. Perubahan komposisi sales mix akan menyebabkan perubahan BEP secara total

2. Cost profit volume Analisys atau analisis Break Even Point disingkat BEP dapat digunakan dalam perencanaan penjualan atau produksi. BEP membantu organisasi atau perusahaan dalam menentukan penjualan atau produksi yang dihasilkan agar mendatangkan laba yang diharapkan.

3. Cost profit volume Analisys atau analisis Break Even Point disingkat BEP dapat digunakan dalam perencanaan harga jual normal. Harga jual yang dapat memberikan laba yang ditargetkan.

4. Cost profit volume Analisys atau analisis Break Even Point disingkat BEP dapat digunakan dalam perencanaan metode produksi. Pemilihan metode produksi yang menghasilkan BEP rendah.

5. Cost profit volume Analisys atau analisis Break Even Point disingkat BEP dapat digunakan dalam penentuan tutup pabrik (shut down point). Apabila penerimaan penjualan melebihi shut down point, maka sebaiknya perusahaan tetap beroperasi, tetapi jika penjualan sudah lebih kecil dari shut down point, sebaiknya perusahaan ditutup sebab perusahaan sudah tidak mampu membayar gaji maupun sewa. 


\section{DAFTAR PUSTAKA}

Brealey,R.,Myers,S, and Allen,F,2006,Corporate Finance,McGraw Hill Foster,G,1986,Financial Statement Analysis, Prentice Hall International

Riyanto Bambang, 2008, Dasar-dasar Pembelanjaan Perusahaan,BPFE, Yogyakarta

Sutrisno, 2012, Manajemen Keuangan, Graha Ilmu, Yogyakarta

Van Horne, J;1989, Financial Management and Policy, Prentice Hall International 